\title{
Vulvar Condyloma Acuminatum
}

National Cancer Institute

\section{Source}

National Cancer Institute. Vulvar Condyloma Acuminatum. NCI Thesaurus. Code C4382.

A benign, human papillomavirus-related neoplasm that arises from the vulva and is characterized by the presence of papillary structures with fibrovascular cores covered by stratified squamous epithelium showing koilocytotic changes. 